\title{
The first detection and molecular characterization of porcine reproductive and respiratory syndrome virus (PRRSV) in Turkey
}

\author{
Taner KARAOGLU ${ }^{1}$, Ender DINCER ${ }^{1}$, Aykut OZKUL ${ }^{1}$ \\ ${ }^{1}$ Faculty of Veterinary Medicine, Department of Virology, Ankara University, Ankara, Turkey.
}

\begin{abstract}
Summary: Porcine Reproductive and Respiratory Syndrome (PRRS) is an important disease that causes severe economic losses in pig industry. PRRSV has two genotypes named as a European (EU) and North American (US). PRRSV appears globally a variety of countries including Canada, USA, South Korea, Germany, Spain, UK, Denmark and Greece. Furthermore, US genotype has been detected serologically in France, Germany and USA in wild boars. So far, no comprehensive information has been generated in Turkey in terms of presence and/or epidemiology of the disease. The aim of this study was to determine presence of PRRSV at initial step and subsequently provide information on possible genotypes that might have occurred in domestic pig and wild boars. The study was carried out on 86 nasal swaps from two different farms and 12 lungs tissue samples from wild boars. A total of $71.4 \%$ of samples were found PRRSV- positive by one-step RT-PCR. Prevalence of the virus in Farms 1 and 2 and wild boars was determined as $76.9 \%, 61.9 \%$ and $58 \%$, respectively. Nucleotide sequence analyses performed on ORF 7 of the genome showed that 96.5\% and 98.2\%, nucleotide homologies in Izmir and Mersin, respectively. In addition, phylogenetic analysis showed that all Turkish PPRSVs was located in the lineage of US like PRRS viruses. This is the first report of PRRSV infection between domestic pigs and wild boars in Turkey.

Key words: PRRS, epidemiology, swine, Turkey.
\end{abstract}

\section{Türkiye'de domuzlarda porcine reproductive and respiratory syndrome virus (PRRSV)'un ilk tesbiti ve moleküler karakterizasyonu}

Özet: Porcine Reproductive and Respiratory Syndrome (PRRS) Virus, domuz endüstrisinde önemli ekonomik kayılara sebep olan bir hastalıktır. Virus, Avrupa ve Kuzey Amerika olmak üzere iki genotipe sahiptir. PRRS virus enfeksiyonu Kanada, Amerika, Kuzey Kore, Almanya, İspanya, İngiltere, Danimarka ve Yunanistan gibi çeşitli ülkelerde görülmektedir. Virusun Kuzey Amerika genotipi Fransa, Almanya ve Amerika'da yaban domuzlarında serolojik olarak tespit edilmiştir. Türkiye'de şimdiye kadar hastalığın varlığına yönelik olarak bir bilgiye ulaşılmamıştır. Bu çalışmada söz konusu enfeksiyonun hem küçük domuz yetiştiriciliklerinde hem de yaban domuzlarında varlığının araştırılması ve sonrasında enfeksiyonu oluşturan virusun genotipine yönelik bilgilerin elde edilmesi amaçlanmıştır. Bu amaçla farklı iki yetiştiricilikten toplam 86 adet nasal swap örneği ile 12 adet yaban domuzundan akciğer doku parçaları alındı. Toplam 98 adet örneğe yapılan one-step RT-PCR testinde \% 71.4'lük pozitiflik saptandı. Virusun prevalansı I. yetiştirilicilikte (İzmir) \%76.9, II. yetiştirilicikte (Mersin) \%61.9 olarak tespit edildi. Yaban domuzlarında ise bu oran \%58.3 olarak saptand1. Nükleotid sekans analizi sonucunda genomun ORF 7 bölgesine I.yetiştiricilikte homoloji \%96.5, II. yetiştiricilikte ise \%98.2 olarak belirlendi. Filogenetik analiz sonucunda çalışmada elde edilen tüm PRRS virusların Amerikan benzeri PRRS virusları içinde yer aldığı tespit edildi. Bu çalışma Türkiye'de evcil ve yaban domuzları arasında PRRSV yönünden yapılan ilk çalışmadır.

Anahtar sözcükler: PRRS, epidemiyoloji, domuz, Türkiye.

\section{Introduction}

Porcine reproductive and respiratory syndrome (PRRS) is characterized by reproductive failure of sows and respiratory problems of piglets and growing pigs and is a significant cause of economic loss.

An important epidemiological feature of PRRSV, as well as other members of the Arteriviridae family, is their ability to induce persistent infectious (4). The importance of persistent infection and contact transmission in the epidemiology of PRRS in emphasized by the fact that, despite extensive replication of PRRSV in the respiratory tract, it is not readily disseminated by aerosols (20).

Additionally, although mechanical vectors of PRRS transmission include contaminated needles (21), fomites and unwashed hands of staff (20), mosquitoes (22), and houseflies (23) the significance of these vectors under field conditions (i.e. in commercial pigs farms). It has been reported that attenuated live vaccine virus can be an effective tool for spreading infection to pigs (6).

PPRSV is a member of the genus Arterivirus, family Arteriviridea, order Nidovirales (7). PPRSV is a 
small enveloped RNA virus that contains a positive-sense and single stranded RNA genome. The genome of PRRSV is approximately $15 \mathrm{~kb}$ and comprises nine open reading frames (ORFs). Structural glycoproteins (gp2 to 5) are expressed by 0RF2- ORF7 $(15,17)$. PRRSV has two genotypes, European and North American, that have been distinguished genetically (24) that one of which was first isolated in the Netherlands (31) while the other type was subsequently described in the USA (5).

The clinical presentation of PRRSV infection depends on the age of the pig infected and on the pregnancy status and trimester of gestation of the infected sow/gilt. Porcine reproductive and respiratory syndrome virus-induced abortion may persist within a herd for periods ranging from 10-12 week up to 4-6 months (1). Reproductive failure resulting from thirdtrimester exposure of pregnant gilts or sows to PRRSV is characterized by late-term abortion or premature farrowing with stillborn fetuses, partially autolyzed fetuses, and mummified fetuses (28).

Clinical signs in infected sows or gilts vary from none to anorexia, fever, lethargy, pneumonia, agalactia, $\mathrm{red} / \mathrm{blue}$ discoloration of the ears and vulva, subcutaneous and hindlimb edema, a post weaning delayed return to estrus and less commonly, death $(10,28)$. Porcine reproductive and respiratory syndrome virus infection in weaned pigs in characterized by fever, pneumonia, lethargy, failure to thrive, and a marked increase in mortality from single to multiple concurrent bacterial infections (28).

In this study, we aimed to detect presence of PPRSV, and to provide information on possible genotypes based on partial characterization of the gene (ORF7) coding for nucleocapsid (N) protein of PRRSVs detected in clinical and/or necropsy samples of domestic and wild porcine. This is the first report on presence of PRRSV infection in Turkey.

\section{Materials and Methods}

Herds and Samples Used: Two private pig farms having different management conditions involved the study. The first farm (F I) located in Izmir province $\left(38^{\circ} 23^{\prime} \mathrm{N}\right.$ and $\left.27^{\circ} 4^{\prime} \mathrm{E}\right)$ and, as far as we learn from questionnaire, the animals moved this location in early 1990s from European Turkey (Thrace), where they were imported from western neighbor countries previously. The herd had some management problems additional to breeding problems such as reproductive failure, low birth weight, stillbirths, mummified pigs/fetal death and respiratory problems such as coughing, pneumonia/rapid breathing, sneezing and blindness. Sixty-five nasal swab samples were collected from this farm. The second farm (F II) located in Mersin province ( $36^{\circ} 48^{\prime} \mathrm{N}$ and $34^{\circ} 38^{\prime} \mathrm{E}$ ) was smaller and had fewer reproductive and/or respiratory problems. Based on herd owner's declaration the majority of animals were originated from F I. A total of twenty-one nasal swap samples were collected from this farm. All animals sampled were under 2 years old of age. Both domestic pig farms have no vaccination history against PRRSV. There was no clinical history of the wild boars and 12 lung tissue samples were collected from them after their in order to investigate presence of PRRSV. The wild boars studied on were thought to be older than 2 years. Numbers of collected samples are given in table 1.

Viral nucleic acid isolation and detection of PRRS virus by one-step RT-PCR: Viral RNA was isolated from nasal swap and lung tissue samples using High Pure Viral Nucleic Acid Isolation kit (Roche, Germany) as described by producer. Each of isolated RNAs was amplified through commercial one-step RT-PCR (VeTek PRRS Detection Kit, Korea) in order to detect PRRSV genome. The kit has been designed to detect PRRSV based on targeting partial (312nt in length) ORF 7 (N protein) sequences. The RT-PCR products were ran on $1,5 \%$ agarose gel and results were examined on transilluminator under ultraviolet (UV) light.

Nucleotide Sequencing and Phylogenetic Analysis: PCR products were gel - purified using a commercial kit (Gel and PCR purification kit, GenMark, Taiwan) and cloned in Pjet1.2 Blunt (Fermentas, Lithuania) according to the manufacturer's protocol. Competent E. coli JM 109 cells were transformed with constructed plasmids. The amplified plasmids were isolated using GeneJet plasmid Miniprep Kit (Fermentas, Lithuania). The constructs were initially verified by digestion with EcoRI restriction enzyme (Fermentas, Lithuania). The plasmid DNAs confirmed was than subjected directly to sequencing in CEQ 8000 Genetic Analyzer (Beckmann Coulter, USA) using the Dye Termination Cycle Sequencing Kit (DTCS, Beckmann Coulter, USA). Sequence analyses were performed simultaneously using plasmid derived sequence primers in both directions at the same time. Sequence editing and multiple alignments were performed with CLCBio Main Workbench v5.0. Partial sequences obtained from ORF7 gene of local PRRSVs were submitted to GenBank. Phylogenetic analysis (Neighbor-Joining) with bootstrap analysis (1,000 replicates) and Kimura 2-parameter correction was conducted by using the MEGA software package v5.0 (12).

Table 1. The number of test samples and RT-PCR results. Tablo 1. Örnekleme sayısı ve RT-PCR sonuçları

\begin{tabular}{lllcc}
\hline Farm & & & \multicolumn{2}{c}{ Number of } \\
Code & Location & Sample & $\begin{array}{c}\text { Sampled } \\
\text { Animals }\end{array}$ & $\begin{array}{c}\text { PRRSV } \\
\text { Positives } \\
(\%)\end{array}$ \\
\hline F I & Izmir & Nasal swap & 65 & $50(76.9)$ \\
F II & Mersin & Nasal swap & 21 & $13(61.9)$ \\
WB & Izmir* & Lung tissue sample & 12 & $7(58.3)$ \\
\hline Total & & & 98 & $70(71.4)$ \\
\hline
\end{tabular}

* Rural area 


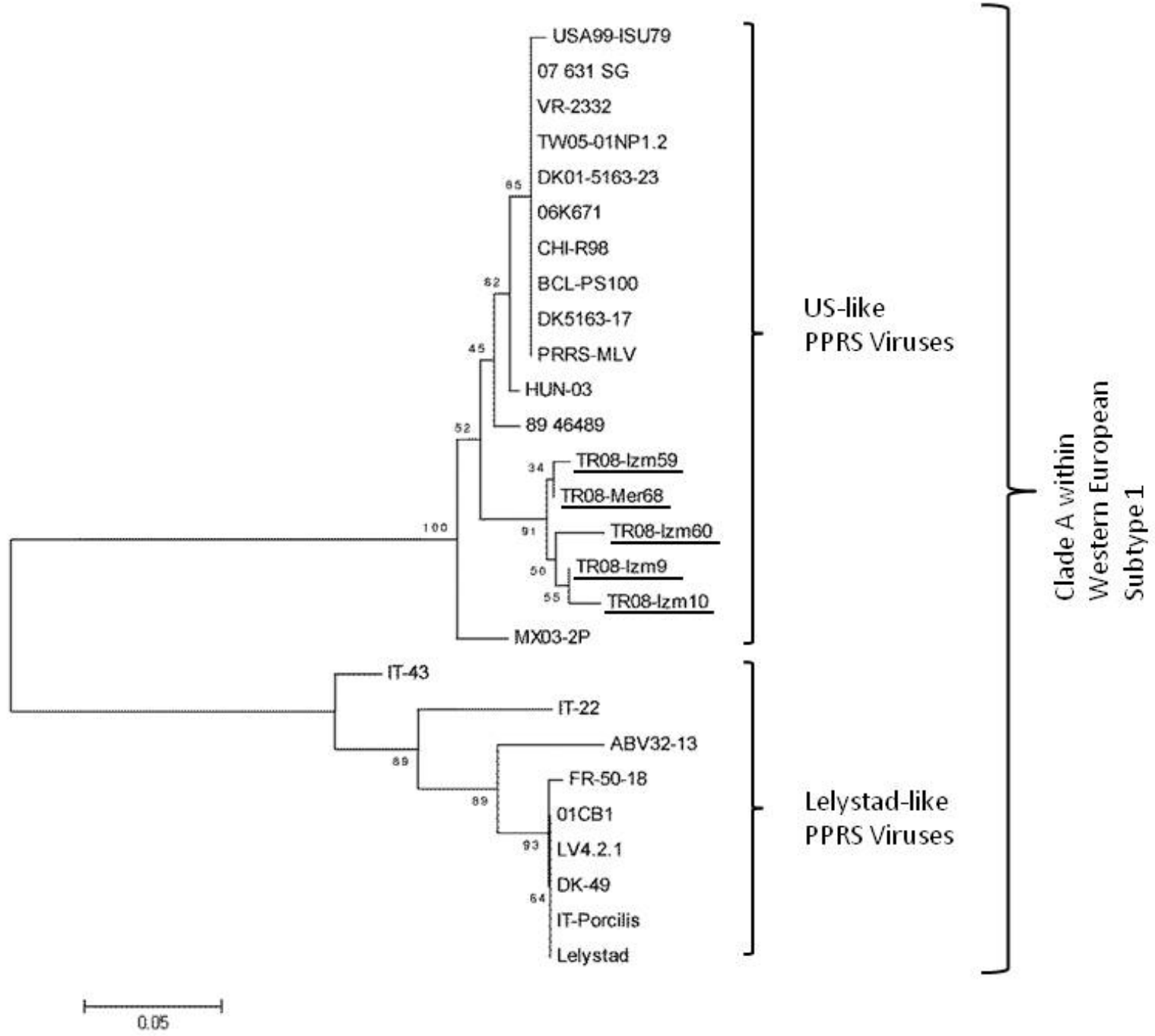

Figure 1. The evolutionary history of Turkish PRRSV isolates indicated as underlined was inferred using the Minimum Evolution method (TR08-Izm9, TR08-Izm10, TR08-Izm59, TR08-Izm60 and TR08-Mer68) in a stretch of nucleotides of the gene coding for the nucleoprotein $(\mathrm{N})$ protein of PRRSVs $(\mathrm{n}=20), 01 C B 1$ (DQ864705), TW05-01NP1 (DQ056373), USA99-ISU79 (U18752), DK5163-17 (AJ223080), MX03-2P (AY209196), LV4.2.1 (AY588319), ABV32-13 (AF297104), VR-2332 (U87392), DK-49 (AF297103), FR-50-18 (AF297102), Porcilis (DQ324710), HUN-03 (GU930363), 07_631_SG (GQ389756), 06K671 (EF441847), 8946489 (AF049966), CHI-R98 (DQ355796), BCL-PS100 (GU187018), DK5163-17 (AJ223080), PRRS-MLV (AF066183), Lelystad (M96262). Numbers at the nodes indicate bootstrapping values. Bar represents nucleotide substitutions per position. Şekil 1. Türkiye'de PRRSV izolatlarının "Minimum Evolution” metodu ile filogenetik analizi.

\section{Results}

A total of seventy samples $(71.4 \%)$ were found PRRSV positive at the end of RT-PCR. The presence of the virus was found more prevalent (76.9\%) in Farm 1 (F1) when compared to Farm 2 (F2; 61.9\%) and wild boars (WB; 58\%) (Table 1). Based on questionnaires, animals in F1 recorded having respiratory and/or reproductive problems.

Out of seven RT-PCR products sequenced, four of them were belonged to farm located in Izmir while the rest were from Mersin. Although wild boars were found PRRSV positive by RT-PCR, no sequence data was obtained because of poor quality of RT - PCR product (data not shown). GenBank accession numbers
HQ343450, HQ343451, HQ343452, HQ343453, HQ343454, HQ343455 and HQ343456 were assigned to TR08-Izm9, TR08-Izm10，TR08-Izm59, TR08-Izm60, TR08-Mer68, TR08-Mer85 and TR08-Mer86 ORF7 partial sequences of local PRRS viruses, respectively. Identity matrices based on partial $\mathrm{N}$ gene coding sequences among the local PRRSV isolates were found varied between 94.7-99.4\%. In addition, average nucleotide identities in locations (Izmir and Mersin) were recorded as $96.5 \%$ and $98.2 \%$, respectively. NeighborJoining analysis based on minimum evolutionary assessments showed that all Turkish PRRSVs located within the lineage of US-like PRRS viruses creating an individual cluster. Although domestic pigs have no 
vaccination history, sequence analysis showed that isolates obtained from two provinces (Mersin and Izmir) shared high nucleotide similarity with PRRS-MLV (AF066183) and VR-2332 (U87392) vaccine strains and clustered in the same lineage (Figure 1). Nucleotide identity between Turkish PRRSV strains and vaccine viruses (PRRS-MLV and VR2332) was found $92.8 \%$ at individual basis.

\section{Discussion}

PRRSV is causative agent of PRRS that cause reproductive failure in pregnant sows and respiratory tract illness in young piglets (16). PRRSV appears globally in domestic pigs and wild boars in a variety of countries including Canada, USA, South Korea, Germany, Spain, UK, Denmark and Greece. Seroprevalances in wild boars for PRRSV have been reported as a $0.4 \%, 1.3 \%$ and $1.7 \%$ in Germany (19), France (2) and the USA, respectively (25). In Greece, it was reported that European PRRSV strains were determined but not North American strains (3). Genetic characterization of PRRSVs can provide new diagnostic tests and vaccines, thus understanding of virus emergence and epidemiology is very important (14). So far, there have been no reports on presence of PPRSV in Turkey.

The present study describes active circulation of PRRSV between domestic pig and wild boar population in Turkey for the first time. In addition, this study shows that there might have exchange of PRRSVs between wildlife and domestic populations. North American genotype of PRRSV can emerge in different locations. For instance, seroprevalence of PRRSV in pig farms in China was approximately $58.6 \%$ and genomic alignment showed that Chinese isolates of PRRSV were $89 \%$ identical to North American viruses while 60\% identical to European viruses (33). In Thailand, PRRS have been found to be caused by individual genotypes (European or North American) or by either genotypes (mix infection). Prevalence of European and North American genotypes in Thailand was reported as $66.42 \%$ and $33.58 \%$, respectively, in the same study (29).

Study result indicated that two domestic pig farms have high level PPRSV infection (71.4\%). This result was found in concordance with previous studies in which North American genotype was found predominantly (33).

As well documented before, wild boars are regarded as reservoir of PRRSV and thus may act as infection source for domestic pigs $(11,13)$. Given the wild boars have been found infected with PRRSV in this study may indicate that they can be infected with PRRSV circulated in domestic pig farms. Therefore, one could be postulated the virus mutually can transmit between domestic and wild animals during food search of wild boars when they come close to domestic pig herds.
Previous investigations proposed that attenuated US-like PRRSV vaccine might be cause of PRRSV in Europe $(18,27)$. This infection of pigs most probably took place after mutation of North American genotype PRRSV vaccine virus $(4,18)$. Similarly, Korean strains of PRRSV isolated from field cases have been shown highly identical to Ingelvac ${ }^{\circledR}$ PRRS-MLV (32). Phylogenetic analysis showed that Turkish PRRSVs are located in the same clade (Clade A) of Western European Subtype I with US-like PRRS viruses. This analysis, which is found in concordance with phylogenetic evolution data reported most recently by Shi et al (26), indicated that the viruses are also very close related to vaccine strains (PRRS-MLV and VR-2332) of PRRS virus. As we know that animals used in this study have never vaccinated against PRRSV, the most logical explanation for this relation is that the virus was acquired when the animals imported (legally or illegally) from a country in which US-like PRRSV positive or attenuated live PRRSV vaccine are routinely used.

Infected semen is also potential source for virus transmission. In a study, Korean isolates was shown of North American origin. The authors reported that stock pigs and semen have been imported from USA and Canada $(8,32)$. Furthermore, Damrongwatanapokin et al, (9) indicated that imported pigs were serologically positive in terms of PRRSV specific antibodies. Based on these data, we speculate that PRRSV might have invaded Turkey via imported (legally or illegally) pigs. Although the locations (Izmir and Mersin) in which PRRSV was detected are distinct from each other, the viruses detected were found closely related. This situation is accepted natural consequence of animal exchange between herds for trade purposes as herd owners declared during questionnaire.

In conclusion, PRRSV was thought to be imported Turkey by means of infected swine from US genotype positive countries. This situation seems to produce serious economical problems for limited number of domestic pig herds in near future. Although pork consumption has religiously forbidden in Muslim countries, touristic hotels and foreign communities can promotes production of pork in increased demand in Turkey as growing industry. To provide about molecular and epidemiologic characterization of PRRSV is very important not only to determine circulating strains in between Turkey and other neighboring countries but also producing healthy meat (and meat products) from well organized domestic pig farms. Wild boar population, which can be reservoir for PRRSV, can easily disseminate virus far fields due to free circulation. As a result, there is need much studies on PRRSV including its geographic distribution, dynamic of genotypes and vaccine alternatives. 


\section{References}

1. Albina E, Madec F, Cariolet R, and Torrison J. (1994): Immune response and persistence of the porcine reproductive and respiratory syndrome virus in infected pigs and farm units. Vet Rec, 134, 567-573.

2. Albina E, Mesplede A, Chenut G, LePotier MF, Bourbao G, LeGal S, and Leforban Y. (2000): $A$ serological survey on classical swine fever (Csf), aujeszky's disease (Ad) and porcine reproductive and respiratory syndrome (PRRS) virus infections in French wild boar from 1991 to 1998. Vet Microbiol, 77, 43-57.

3. Alexopoulos C, Kritas SK, Kyriakis CS, Tzika E, and Kyriakis SC. (2003): The effect of vaccination of sows with an attenuated PRRSV vaccine an their health status and performance in a farm with endemic PRRSV infection. 4th International Symposium Emerging and Re-emerging Pig Diseaes - Rome. June 29th-July 2nd.

4. Allende R, Laegreid WW, Kutish GF, Galeota JA, Wills RW, and Osorio FA. (2000): Porcine reproductive and respiratory syndrome virus: description of persistence in individual pigs upon experimental infection. J Virol, 74, 10834-10837.

5. Benfield DA, Nelson E, Collins JE, Haris L, Goyal SM, Robison D, Christianson WT, Morrison RB, Gorcyca D, and Chladek D. (1992): Characterization of swine infertility and respiratory syndrome (SIRS) virus (isolate ATCC VR-2332). J Vet Diag Invest, 4, 127-133.

6. Botner A, Strandbygaard B, Sorensen KJ, Have P, Madsen KG, Madsen ES, and Alexandersen S. (1997): Appearance of acute PRRS-like symptoms in sow herds after vaccination with a modified live PRRS vaccine. Vet Rec, 141, 497-499.

7. Cavanagh D. (1997): Nidovirales: a new order comprising Coronavirdea and Arteriviridea. Arch.Virol, 142, 629-633.

8. Cha S-H, Choi E-J, Park J-H, Yoon S-R, Song J-Y, Kwon J-H, Song H-J, and Yoon K-J. (2006): Molecular characterization of recent Korean porcine reproductive and respiratory syndrome (PRRS) viruses and comparison to other Asian PRRS viruses. Vet Microbiol, 117, 248-257.

9. Damrongwatanapokin S, Arsayuth K, Kongkrong C, Parchariyanon S, Pinyochon W, and Tantaswasdi U. (1996): Serological studies and isolation of porcine reproductive and respiratory syndrome (PRRS) virus in Thailand. J Thai Vet Med Assoc, 47, 19-30.

10. Done SH, and Paton DJ. (1995): Porcine reproductive and respiratory syndrom: clinical disease, pathology and immunosupression. Vet Rec, 136, 32-35.

11. Elbers ARW, Dekkers LJM, and Van Der Giessen JWB.. (2000): Sero-surveillance of wild boar in the Netherlands,1996 -1999. Rev Sci Tech Off Epizoo, 19, $848-854$.

12. Kumar S, Tamura K, and Nei M. (2004): MEGA3: Integrated software for molecular volutionary genetics analysis and sequence alignment. Brief Bioinform, 5, 150163.

13. Labddomada A. (2000): Incidence and control of CSF in wild boar in Europe. Vet Microbiol, 73, 121-130.

14. Meng XJ. (2000): Heterogeneity of porcine reproductive and respiratory syndrome virus: implications for current vaccine efficacy and future vaccine development. Vet Microbiol, 74, 309-329.
15. Meulenberg JJM, Hulst MM, DeMeijer EJ, Moonen PLJM, Den Besten A, DeKluyver EP, Wensvoort G, and Moormann RJM. (1993): Lelystad virus, the causative agent of porcine epidemic abortion and respiratory syndrome (Pears), Is related to LDV and EAV. Virology, 192, 62-72.

16. Meulenberg JJM. (1998): Porcine reproductive and respiratory syndrome virus (PRRSV) molecular characterization of the agent. In: proceedings of fifteenth IPVS congress, Birmingham, 149-157.

17. Murtaugh MP, Elam MR, and Kakach LT. (1995): Comparison of the structural protein coding sequences of the VR-2332 and Lelystad virus strains of the PRRS virus. Arch Virol, 140, 1451-1460.

18. Nielsen J, Botner A, Bille-Hansen V, Oleksiewichz MB, and Storgaard T. (2002): Experimantal inoculation of late term pregnant sows with a field isolate of porcine reproductive respiratory syndrome vaccine - derived virus. Vet Microbiol, 84, 1-13.

19. Oslage U, Dahle J, Muller T, Kramer M, Biereir D, and Liess B. (1994): Antibody prevalence of hog cholera, Aujeszky's disease and the porcine reproductive and respiratory syndrome virus in wild boar in the Federal States Saschen Anhalt and Brandeburg (Germany). DTW, 101, 33-38.

20. Otake S, Dee SA, Rossow KD, Deen J, Joo HS, Molitor TW, and Piojan J. (2002): Transmission of porcine reproductive and respiratory syndrome virus by fomites (boots and coveralls). J Swine Health Prod, 10, 59-65.

21. Otake S, Dee SA, Rossow KD, Joo HS, Deen J, Molitor TW, and Piojan J. (2002): Transmission of porcine reproductive and respiratory syndrome virus by needles. Vet Rec, 150, 114-115.

22. Otake S, Dee SA, Rossow KD, Moon RD, and Pijoan J. (2002): Mechanical transmission of porcine reproductive and respiratory syndrome virus by mosquitoes, Aedes vexans (Meigen). Can J Vet Res, 66, 191-195.

23. Otake S, Dee SA, Rossow KD, Moon RD, Tricado C, and Pijoan C. (2003): Transmission of porcine reproductive and respiratory syndrome virus by houseflies (Musca domestica). Vet Rec, 152, 73-76.

24. Plagemann PGW. (2003): Porcine reproductive and respiratory syndrome virus: Origin Hypotthesis. Emerg Infec Diseseases, 9, 8.

25. Saliki JT, Rodgers SJ, and Eskew G. (1998): Serosurvey of selected viral and bacterial diseases in wild swine from Oklahoma. Journal of Wildlife Diseases, 34, 834-838.

26. Shi M, Lam TTY, Hon CC, Hui RKH, Faaberg KS, Wennblom T, Murtaugh MP, Stadejek T, Leung FCC. (2010): Molecular epidemiology of PRRSV : A phylogenetic perspective. Virus Res, 154, 7-17.

27. Storgaard T, Oleksiewicz M, and Botner A. (1999): Examination of the selective pressures on a live PRRSV vaccine virus. Arch Virol, 144, 2389-2401.

28. Terpstra C, Wensvoort G, and Pol JMA. (1991): Experimental reproduction of porcine reproductive and respiratory syndrome (mystery swine disease) by infection with Lelystad virus: koch's postulated fulfilled. Vet Q, 13, 131-136.

29. Thanawongnuwech R, Amonsin A, Tatsanakit A, and Damrongwatanapokin S. (2004): Genetics and 
geographical variation of porcine reproductive and respiratory syndrome virus (PRRSV) in Thailand. Vet Microbiol, 101, 9-21.

30. Torremorell M, Pijoan C, Janni K, Walker R, and Joo HS. (1997): Airborne transmission of Actinobacillus pleuropneumoniae and porcine reproductive and respiratory syndrome virus in nursery pigs. Am J Vet Res, 58, 828-832.

31. Wensvoort G, Terpstra C, Pol JM, terLaak EA, Bloemraad M, de Kluyver EP, Kragten C, van Buiten L, den Besten A, Wagenaar F, Broekhuhsen JM, Moonen PLJM, Zetstra T, de Boer EA, Tibben HJ, de Jong MF, van't Veld P, Greenland GJR, van Gennep JA, Th. Voets M, Verheijden JHM, and Braamskamp J. (1991): Mystery swine disease in the Netherlands:the isolation of Lelystad virus. Veterinary Quarterly, 13, 121130.
32. Yoon SH, Song JY, Lee CH, Choi EJ, Cho IS, and Kim B. (2008): Genetic characterization of the Korean porcine reproductive and respiratory syndrome viruses based on the nucleocapsid protein gene (ORF7) sequences. Arch Virol, 153, 627-635.

33. Zhou L, and Yang H. (2010): Porcine reproductive respiratory sydrome in China. Virus Research, 154, 31-37.

Geliş tarihi: 20.02.2012 / Kabul tarihi: 19.03.3012

\author{
Address for correspondence: \\ Taner Karaoglu, \\ Faculty of Veterinary Medicine, \\ Department of Virology, Ankara University, \\ Ankara, Turkey. \\ Tel.: +90 3123170315 ext.366; \\ Fax: +90 3123173348 ; \\ E-mail:karaoglu@ankara.edu.tr
}

